\title{
Comparison of serum protein electrophoretic pattern in cows and small ruminants
}

\author{
Oskar Nagy, Csilla Tóthová, Veronika Nagyová, Gabriel Kováč \\ University of Veterinary Medicine and Pharmacy, Clinic for Ruminants, Košice, \\ Slovak Republic
}

Received August 27, 2014

Accepted November 26, 2014

\begin{abstract}
Determination of the physiological electrophoretic patterns in animals is very useful for clinicians in diagnosing healthy and sick animals. The objective of this study was to investigate the serum protein electrophoretic pattern in cows, sheep, and goats in order to evaluate the differences in the size and number of protein fractions between the evaluated ruminant species. Ten adult multiparous high-yielding dairy cows, 10 adult female sheep and 10 adult female goats were included in this study. All the evaluated animals were clinically healthy. Serum was analyzed for total serum protein concentrations, and for the relative and absolute values of protein fractions with calculation of albumin/globulin ratios. Serum protein fractions were separated by zone electrophoresis on buffered agarose gel. Serum protein electrophoresis identified 6 distinct bands, comprising albumin, alpha $-\left(\alpha_{1}\right)$, alpha ${ }_{2}\left(\alpha_{2}\right)$, beta $-\left(\beta_{1}\right)$, beta $-\left(\beta_{2}\right)$, and gamma- $(\gamma)$ globulins in cows. In sheep, serum proteins exhibited 6 fractions: albumin, $\alpha_{1}-, \alpha_{2}-, \beta-, \gamma_{1}$ and $\gamma_{2}$-globulins. In goats, serum proteins were separated into 5 fractions: albumin, $\alpha_{1^{-}}, \alpha_{2}-, \beta-$ and $\gamma$-globulins. Significant differences in the relative as well as absolute means were found for the albumin/globulin ratio and most of the protein fractions, except $\gamma$-globulins. No significant differences were found in the concentration of total proteins. These results describe the marked species differences in most of serum protein fractions between the evaluated groups of animals, and contribute to the current knowledge about the physiological electrophoretic pattern of serum proteins in ruminants, which can be used for diagnostic purposes.
\end{abstract}

Cattle, sheep, goat, total proteins, protein fractions, gel electrophoresis

Hundreds of different proteins with a wide variety of functions circulate in blood and concentrations of total proteins and several specific proteins are of clinical value (Joliff 1992). When tissues responsible for the synthesis or excretion of proteins are altered by disease, the resulting serum produces distinctive patterns of proteins that could be helpful in diagnosis (Joliff 1991). Modifications of total serum protein concentrations, the fractional distribution of blood proteins and albumin/globulin ratio are usually the first signs of protein abnormality (Dede et al. 2014). Electrophoresis is a suitable separation technique for fractination and quantification of serum proteins, and for the monitoring of changes in serum protein fractions. It is based on the movement of charged particles through a solution when subjected to an electrical field (Azim et al. 2004). Serum proteins have a negative charge, so they migrate in an electrical field and are separated from each other in different bands (Esmaeilnejad et al. 2014). Following electrophoresis, serum proteins can be separated into four fractions including albumin, and alpha $(\alpha)$-, beta $(\beta)$ and gamma $(\gamma)$-globulin fractions (Bossuyt 2006). Each band is made up of a group of individual proteins, each of which is characterized by independent metabolic properties. Although protein electrophoresis has been extensively used as an effective diseasescreening tool in human medicine for many years, this technique is not commonly used in veterinary medicine (Wijnen and Van Dieijen-Visser 1996; O'Connell et al. 2005). Although this test has low specificity in the diagnosis, determination of the physiological electrophoretic patterns in all domestic animals and correct interpretation of their results is very useful for clinicians in diagnosing healthy and infected animals (Lutz et al. 2009). 
The distribution and concentration of blood proteins is affected by many diseases. Identifying and quantifying protein fractions enable the identification of animals with altered serum protein pattern, which may reflect responses to changes in homeostasis or disease (Alberghina et al. 2011). Many times, abnormalities found in the proteinogram are not related to illness but to physiological and individual conditions (França et al. 2011). The interpretation of biochemical constituents depends on the knowledge of variation that exists not only among different species of animals, but also among different groups of animals. Some researchers noted that serum protein fractions display important differences among all domestic animals (Keay and Doxey 1981; Alberghina et al. 2010). As the number of protein fractions varies with the species, determination of the normal electrophoretic pattern of each species appears to be essential (Ahmadi-Hamedani et al. 2014). However, only a few studies have described the differences in the electrophoretic mobility of serum proteins between ruminant species. Therefore, the aim of this study was to determine the physiological serum protein electrophoretic pattern for selected ruminant species, and to describe the possible differences in protein fractions between the evaluated groups of animals.

\section{Materials and Methods}

To obtain the differences in the serum protein electrophoretic pattern between ruminants, 10 adult multiparous high-yielding dairy cows at the peak of lactation, 10 adult female sheep and 10 adult female goats from conventional farms were included in this study. The evaluated cows were of the Slovak Pied breed and its crossbreeds at the age of 3-5 years, with a mean body weight of $453 \pm 32 \mathrm{~kg}$ and daily milk yield of $28 \pm 5$ litres. The cows were housed in free-stalls, and fed twice a day diets for lactating cows with free access to water in automatic drinking troughs. They were milked twice a day. The evaluated sheep were of the merino breed at the age of 2-4 years, with a mean body weight of $48 \pm 6 \mathrm{~kg}$. The goats were of the white shorthaired breed, 2-4 years old and with a mean body weight of $35 \pm 5 \mathrm{~kg}$. All the evaluated sheep and goats had free access to water and alfalfa hay. The concentrate was provided once daily. Before blood sample collection, the animals used in the study were examined clinically using standard clinical examination procedures. All the animals were clinically healthy and in good general health condition without any obvious clinical signs of disease. Blood samples were collected through jugular venipuncture using plastic serum gel separator tubes without anticoagulant (Meus, Piove di Sacco, Italy). Blood samples were allowed to clot at room temperature, and then centrifuged at $3000 \times g$ for 30 min to separate serum. Harvested blood serum was dispensed into plastic tubes, and stored at $-20{ }^{\circ} \mathrm{C}$ until analysed.

Serum was analysed for the concentrations of total proteins (TP, g/l) and serum protein fractions (albumin, $\mathrm{a}-, \beta-$, and $\gamma$-globulins). Total protein concentrations were assessed on an automated biochemical analyser Alizé (Lisabio, France) by the biuret method using commercial diagnostic kits (Randox Laboratories, United Kingdom). Serum protein fractions were separated by zone electrophoresis on buffered agarose gel at $\mathrm{pH} 8.8$ on an automated electrophoresis system (Hydrasys, Sebia Corporate, Evry-Paris, France) using commercial diagnostic kits (Hydragel 7 Protein, Sebia Corporate, Evry-Paris, France) according to the procedure described by the manufacturer. Electrophoretic gels were scanned, and the serum protein fractions were visualized and displayed on densitometry system (Epson Perfection V700, Epson America Inc., Long Beach, California, USA) by light transmission and automatic convertion into an optical density curve presentation. Protein fractions were identified and quantified by computer software (Phoresis version 5.50, Sebia Corporate, Evry-Paris, France), and if necessary, corrected by visual inspection of the electrophoretogram. The relative concentrations (\%) of the protein fractions were determined as the percentage of optical absorbance, and the absolute concentrations ( $\mathrm{g} / \mathrm{l})$ were calculated from the total serum protein concentrations. Albumin:globulin ratios $(A / G)$ were computed from the electrophoretic scan.

Arithmetic means (x) and standard deviations (SD) for each evaluated variable and group of animals were calculated using descriptive statistical procedures. One-way analysis of variance (ANOVA) with a Tukey's multiple comparison test were applied to evaluate the significance of differences in means between the groups of animals. All statistical analyses were done using the programme GraphPad Prism V5.02 (GraphPad Software Inc., USA).

\section{Results}

The data referring to the relative and absolute concentrations of serum protein fractions in the evaluated groups of animals expressed as means and standard deviations, including the significance of differences in the means between the groups are presented in Tables 1 
Table 1. The relative concentrations of serum protein fractions (\%) and albumin/globulin ratios in cows, sheep and goats (mean $\pm \mathrm{SD})$.

\begin{tabular}{|c|c|c|c|c|}
\hline \multirow{2}{*}{ Variables } & \multicolumn{3}{|c|}{ Group of animals } & \multirow{2}{*}{$\begin{array}{c}P \\
\text { value }\end{array}$} \\
\hline & Cows & Sheep & Goats & \\
\hline Albumin & $44.9 \pm 4.3^{\mathrm{c}}$ & $55.8 \pm 4.3^{\mathrm{d}}$ & $46.5 \pm 4.1^{\mathrm{c}}$ & $<0.001$ \\
\hline$\alpha$ & $18.6 \pm 1.1^{\mathrm{a}}$ & $17.0 \pm 1.9^{\mathrm{c}}$ & $21.8 \pm 2.2^{\mathrm{bd}}$ & $<0.001$ \\
\hline$\alpha_{1}$ & $6.3 \pm 0.7^{c}$ & $5.8 \pm 0.7^{\mathrm{c}}$ & $8.7 \pm 1.2^{\mathrm{d}}$ & $<0.001$ \\
\hline$\alpha_{2}$ & $12.3 \pm 0.7$ & $11.2 \pm 1.3^{\mathrm{a}}$ & $13.2 \pm 1.8^{\mathrm{b}}$ & $<0.05$ \\
\hline$\beta$ & $13.2 \pm 1.3^{\mathrm{a}}$ & $4.7 \pm 0.8^{\mathrm{b}}$ & $6.3 \pm 2.0^{\mathrm{b}}$ & $<0.001$ \\
\hline$\beta_{1}$ & $7.4 \pm 0.6$ & & & \\
\hline$\beta_{2}$ & $5.8 \pm 1.0$ & & & \\
\hline$\gamma$ & $23.4 \pm 2.9$ & $22.5 \pm 3.0$ & $25.4 \pm 3.7$ & n.s. \\
\hline$\gamma_{1}$ & & $18.9 \pm 2.8$ & & \\
\hline$\gamma_{2}$ & & $3.6 \pm 1.0$ & & \\
\hline $\mathrm{A} / \mathrm{G}$ & $0.83 \pm 0.15^{\mathrm{c}}$ & $1.28 \pm 0.23^{\mathrm{d}}$ & $0.88 \pm 0.16^{\mathrm{c}}$ & $<0.001$ \\
\hline
\end{tabular}

$\mathrm{A} / \mathrm{G}-$ albumin/globulin ratio; $\alpha, \beta, \gamma-\alpha, \beta, \gamma$ globulins; n.s. - not significant

$\mathrm{a}, \mathrm{b}, \mathrm{c}, \mathrm{d}-$ means with different superscripts in rows differ significantly: $\mathrm{a}, \mathrm{b}-P<0.01 ; \mathrm{c}, \mathrm{d}-P<0.001$

Table 2. Concentrations of serum total proteins and serum protein fractions $(\mathrm{g} / \mathrm{l})$ in cows, sheep, and goats (mean $\pm \mathrm{SD})$.

\begin{tabular}{lcccc}
\hline Variables & \multicolumn{3}{c}{ Group of animals } & $\begin{array}{c}P \\
\text { value }\end{array}$ \\
\cline { 2 - 5 } TP & Cows & Sheep & Goats & n.s. \\
Albumin & $75.0 \pm 3.0$ & $69.8 \pm 3.5$ & $73.5 \pm 6.6$ & $<0.01$ \\
$\alpha$ & $33.6 \pm 2.5^{\mathrm{a}}$ & $39.0 \pm 3.9^{\mathrm{b}}$ & $34.1 \pm 3.3^{\mathrm{a}}$ & $<0.001$ \\
$\alpha_{1}$ & $14.0 \pm 1.3^{\mathrm{xa}}$ & $11.9 \pm 1.2^{\mathrm{bc}}$ & $16.0 \pm 1.8^{\mathrm{dy}}$ & $<0.001$ \\
$\alpha_{2}$ & $4.7 \pm 0.6^{\mathrm{c}}$ & $4.1 \pm 0.5^{\mathrm{c}}$ & $6.4 \pm 1.1^{\mathrm{d}}$ & $<0.001$ \\
$\beta^{\mathrm{a}}$ & $9.3 \pm 0.8^{\mathrm{a}}$ & $7.8 \pm 0.8^{\mathrm{bc}}$ & $9.6 \pm 1.0^{\mathrm{d}}$ & $<001$ \\
$\beta_{1}$ & $9.9 \pm 1.2^{\mathrm{c}}$ & $3.3 \pm 0.6^{\mathrm{dx}}$ & $4.7 \pm 1.6^{\mathrm{dy}}$ & n.s. \\
$\beta_{2}$ & $5.5 \pm 0.5$ & & & $18.8 \pm 3.9$ \\
$\gamma_{1}$ & $4.4 \pm 0.9$ & & & \\
$\gamma_{2}$ & $17.5 \pm 2.5$ & $15.7 \pm 2.2$ & & \\
\hline
\end{tabular}

$\mathrm{TP}$ - total proteins; $\alpha, \beta, \gamma-\alpha, \beta, \gamma$ globulins; n.s. - not significant

$\mathrm{x}, \mathrm{y}, \mathrm{a}, \mathrm{b}, \mathrm{c}, \mathrm{d}-$ means with different superscripts in rows differ significantly: $\mathrm{x}, \mathrm{y}-P<0.05 ; \mathrm{a}, \mathrm{b}-P<0.01$;

$\mathrm{c}, \mathrm{d}-P<0.001$

and 2. Serum protein electrophoresis identified 6 distinct bands, comprising albumin, two $\alpha$-globulin $\left(\alpha_{1}\right.$ and $\left.\alpha_{2}\right)$, two $\beta$-globulin $\left(\beta_{1}\right.$ and $\left.\beta_{2}\right)$, and $\gamma$-globulin fractions in cows (Table 1 , Fig. 1). In sheep, serum proteins exhibited 6 fractions: albumin, two $\alpha$-globulin $\left(\alpha_{1}\right.$ and $\left.\alpha_{2}\right)$, $\beta$-globulin and $\gamma$-globulin fractions divided into $\gamma_{1}$ and $\gamma_{2}$-globulins (Fig. 2). In goats, serum proteins were separated into 5 fractions: albumin, two $\alpha$-globulin $\left(\alpha_{1}\right.$ and $\left.\alpha_{2}\right), \beta$-globulin, and $\gamma$-globulin fractions (Fig. 3). Albumin was the most prominent protein fraction in all of the evaluated ruminants, and constituted on average $44.9,55.8$ and $46.5 \%$ of total serum proteins in cows, sheep and goats, respectively. The results found in these ruminants differed significantly $(P<0.001)$. Highly significant differences between the evaluated groups 
of animals were found also for $\alpha$-and $\alpha_{1}$-globulins, with significantly the highest relative concentrations in goats $(P<0.001)$. Similar trend was observed in the relative values of $\alpha_{2}$-globulins $(P<0.05)$ with significantly higher relative concentrations of this fraction in goats than in sheep $(P<0.01)$. Significant differences were detected also in the relative concentrations of $\beta$-globulins $(P<0.001)$. The results obtained in samples from cows were significantly higher than the values recorded in sheep, as well as in goats $(P<0.001)$. On the other hand, the $\gamma$-globulin fraction did not show significant differences between the evaluated groups of animals. Non-significantly the highest mean relative concentration of this fraction was found in goats. For the $\mathrm{A} / \mathrm{G}$ ratio, significant differences between ruminant species were observed, with the highest mean values found in sheep $(P<0.001)$.

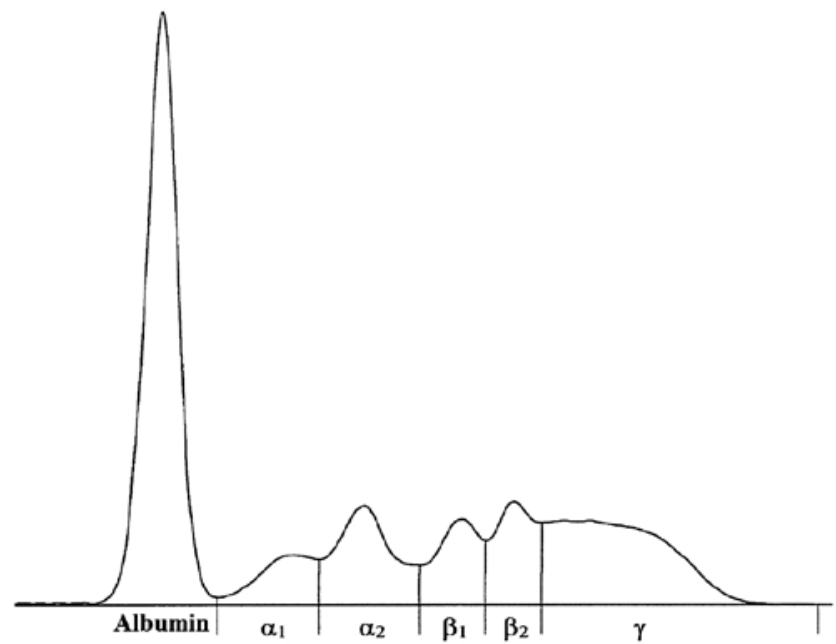

Fig. 1. Representative agar gel electrophoretic pattern of serum sample from a healthy cow

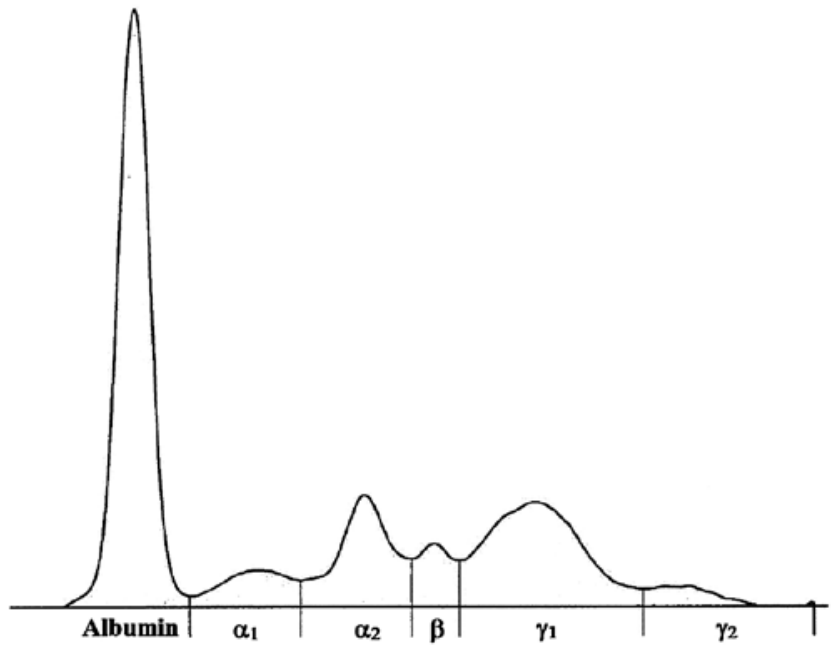

Fig. 2. Representative agar gel electrophoretic pattern of serum sample from a healthy sheep 

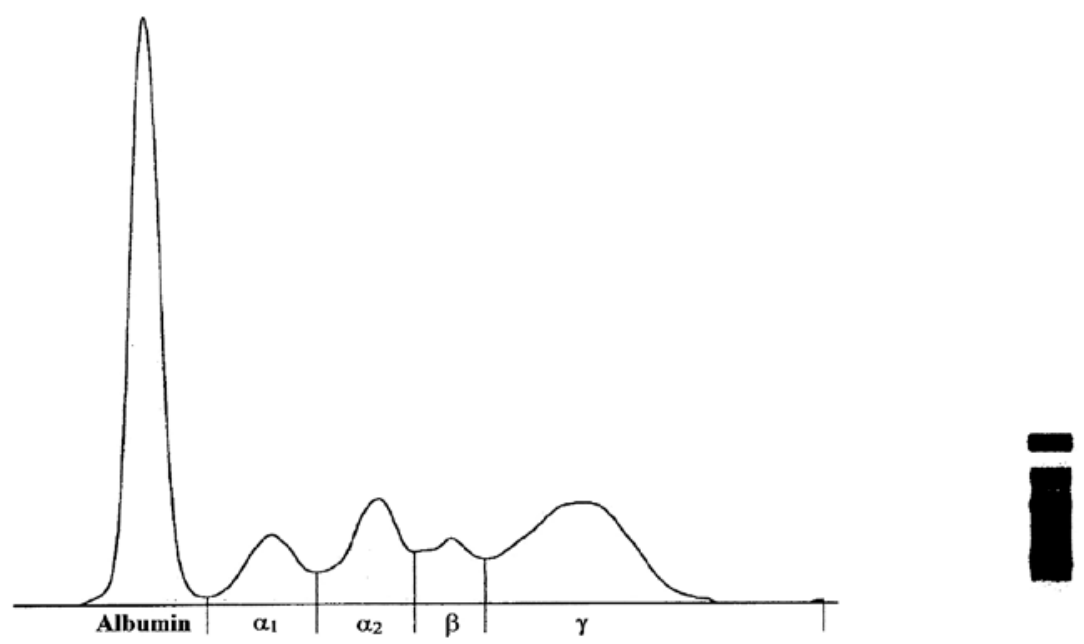

Fig. 3. Representative agar gel electrophoretic pattern of serum sample from a healthy goat

The concentrations of total proteins in the blood serum of ruminants showed no significant differences (Table 2). Analysing the absolute concentrations of serum protein fractions, depending on the evaluated species, significant differences were found in almost all protein fractions, except for $\gamma$-globulins. The concentrations of albumin in sheep were significantly higher than those found in cows, as well as in goats $(P<0.01)$. Significant differences between the evaluated animals were detected also in the absolute values of $\alpha$-globulins, with significantly higher concentrations in goats compared to cows and sheep $(P<0.001)$. Significant differences in the evaluated ruminant species were found for $\beta$-globulins $(P<0.001)$. The highest mean value was found in cows. In small ruminants this fraction was not divided into 2 subfractions $\left(\beta_{1}\right.$ and $\left.\beta_{2}\right)$. No significant differences between the evaluated groups of animals were found in the absolute concentrations of $\gamma$-globulins. The lowest values were recorded in sheep with separation into 2 subfractions $\left(\gamma_{1}\right.$ and $\left.\gamma_{2}\right)$.

\section{Discussion}

In routine clinical chemistry, electrophoresis is the standard method for the estimation of serum protein fractions. Typically, proteins are separated into 5 fractions in humans: albumin, $\alpha_{1}-, \alpha_{2}-, \beta$-, and $\gamma$-globulins (Bossuyt et al. 2001). However, in veterinary medicine more fractions inside $\beta$-globulins and even $\gamma$-globulins have been described. According to Luraschi et al. (2003), the protein patterns and numbers of peaks obtained are dependent on the sensitivity of the electrophoresis used (cellulose acetate or agarose gel electrophoresis). On the other hand, there are also considerable species and breed variations in the number, shape, and size of fractions and subfractions (F ayos et al. 2005).

A frequent difficulty in dealing with serum protein electrophoresis of domestic animals is the difference in the normal physiological pattern between the species. This has created some differences in the identification of particular fractions of the electrophoretogram as $\alpha, \beta$ or $\gamma$ by various authors. In our study, agarose gel electrophoresis of serum proteins in bovine samples identified six fractions comprising albumin, $\alpha_{1}-$ and $\alpha_{2}-, \beta_{1}-$ and $\beta_{2}-$, and $\gamma$-globulins. Kaneko (1997) mentions only 4 fractions by protein electrophoresis of bovine serum using cellulose acetate, including albumin, $\alpha$-, $\beta$-, and $\gamma$-globulins. In recent studies, Alberghina et al. (2011) and Piccione et al. (2012) described the separation of 
bovine serum by agarose gel electrophoresis into 5 fractions, comprising albumin, $\alpha_{1^{-}}, \alpha_{2^{-}}$, $\beta$-, and $\gamma$-globulins. Agarose gel as a support medium provides better resolution, higher reproducibility of results and greater clarity of the electrophoretic bands (Riond et al. 2009). Serum protein electrophoresis in small ruminants has not been described in such detail as in cattle, but it appears that the number of protein fractions in sheep and goats is different. While in sheep serum proteins were separated into albumin, $\alpha_{1^{-}}, \alpha_{2}^{-}, \beta-, \gamma_{1}^{-}$, and $\gamma_{2}$-globulins, electrophoresis in goats showed albumin, $\alpha_{1^{-}}, \alpha_{2}^{-}, \beta$-, and $\gamma$-globulin fractions. Esmaeilnejad et al. (2014) observed also by protein electrophoresis of serum from healthy sheep albumin, $\alpha-, \beta$-, and $\gamma$-globulin fractions, while similarly to our results the $\alpha$ - and $\gamma$-globulin bands were divided into $\alpha_{1}$ - and $\alpha_{2}-\gamma_{1}-$, and $\gamma_{2}$-globulins. The number of protein fractions peaking in goat serum varied between various authors. Pérez et al. (2003) recognized two $\alpha$-globulin and one $\beta$-globulin fractions in goats using acetate cellulose as electrophoretic matrix. On the other hand, Cyrillo et al. (2006), Fernandez et al. (2006) and Alberghina et al. (2010) found one $\alpha$-globulin and two $\beta$-globulin fractions in the goat. According to these authors, the separation of serum proteins into 5 fractions (albumin, $\alpha_{1}^{-}, \alpha_{2}-, \beta$ - and $\gamma$-globulins) is usually sufficient for diagnostic purposes.

Albumin is often considered the only discrete and homogenous protein fraction discernible on the electrophoretogram. In animals, it constitutes between $35-50 \%$ of the total serum proteins (Kaneko 1997). The shape and size of albumin fraction was very similar in all the evaluated ruminant species reflecting its high serum concentration, homogenous electric charge and high staining afinity (Keren 2003). Significant differences were found in its relative concentrations between the groups of animals in our study, with the lowest mean value in cows (44.9\%) and the highest mean value in sheep (55.8\%). Similar, but slightly higher relative concentrations of albumin (on average $47.1 \%$ ) were reported in clinically healthy dairy cows by Alberghina et al. (2011). Identification and quantification of the concentrations of serum proteins in sheep and goats have been rarely described. Our results obtained in goats are comparable with the data presented by Alberghina et al. (2010) and Janku et al. (2011). On the other hand, Fernandez et al. (2006) observed lower albumin values in goats probably due to using a different support medium. Moreover, the proteins of an individual or of a species, including albumin, are synthesized under genetic control (Kaneko 1997). Therefore, the variations found in the concentrations of albumin may be caused by these species differences in the physiological concentrations of several proteins.

Globulins are a very heterogenous group of proteins that can be classified as $\alpha-, \beta$ - or $\gamma$-globulins by electrophoresis. Depending on the species, there may normally be one or two $\alpha$, one or two $\beta$, and one or two $\gamma$ fractions (Kaneko 1997). The $\alpha$ fraction is the most rapidly migrating of all the globulins, and in most species it migrates as $\alpha_{1}$ (fast) and an $\alpha_{2}$ (slow) fraction. In our study, the $\alpha$-globulins migrated into 2 zones $\left(\alpha_{1}\right.$ and $\left.\alpha_{2}\right)$ in cows, sheep, as well as goats, but the relative concentrations of these two fractions were significantly different. In general, the values of $\alpha_{1}$-globulins were lower than $\alpha_{2}$-globulins in all the evaluated animals. In cows, the $\alpha_{1}$-globulin fraction constituted on average $6.3 \%$ of the total serum protein concentration, whereas the mean relative concentration of $\alpha_{2}$-globulins was $12.3 \%$. Similar findings were reported in healthy cattle by Dede et al. (2014). Alberghina et al. (2011) observed in clinically healthy dairy cows also two $\alpha$ zones, while the $\alpha_{1}$ - and $\alpha_{2}$-globulins constituted 8.53 and $8.74 \%$ of the total serum protein concentration, respectively. Serum protein electrophoresis allowed the separation of $\alpha$-globulins into two zones also in sheep, which is in agreement with the data observed by Esmaeilnejad et al. (2014). These authors presented only the absolute concentrations of several fractions, but the values are comparable to our results $\left(2.7\right.$ and $8.0 \mathrm{~g} / 1$ for $\alpha_{1}$ - and $\alpha_{2}$-globulins, respectively). In goats, $\alpha$-globulins migrated also as $\alpha_{1}$ - and $\alpha_{2}$-globulin band, but their relative concentrations were significantly higher compared to cows and sheep. Similarly, Janku et al. (2011) presented in goats two $\alpha$-globulin zones, but they calculated 
only the absolute values of the fractions, which were lower compared to our results. On the other hand, Fernandez et al. (2006) and Alberghina et al. (2010) identified only one $\alpha$-globulin fraction in goats. These contradictory results could be due to different electrophoretic techniques used for the separation of protein fractions (Alberghina et al. 2010). Moreover, many diagnostically important acute phase proteins occur in this fraction. Alpha $a_{1}$-antitrypsin, $\alpha_{1}$-acid glycoprotein, and $\alpha_{1}$-lipoprotein have been identified in the $\alpha_{1}$-globulin fraction, while haptoglobin, $\alpha_{2}$-microglobulin, $\alpha_{2}$-macroglobulin, ceruloplasmin and $\alpha_{2}$-lipoprotein in the $\alpha_{2}$-globulin fraction (Bossuyt 2006). Acute phase proteins are a large and varied group of plasma proteins, with numerous differences in their concentrations between different animal species (Eckersall and Bell 2010). Thus, the electrophoretic pattern of serum proteins may be influenced by varied concentrations of several proteins from this fraction also in the evaluated ruminant species. Beta-globulins are a group of globular proteins that are more mobile in electrically charged solutions than $\gamma$-globulins, but less mobile than $\alpha$-globulins. In our study, they migrated differently in cows $\left(\beta_{1}\right.$ and $\beta_{2}$ ) compared to sheep and goats (only 1 fraction). In the concentrations of $\beta$-globulins differences were observed between the evaluated ruminants species, with the highest values measured in cows. The $\beta$-globulin fraction constituted $7.4 \%$ of the total serum protein concentrations in cows, whereas the $\beta_{2}$-globulins constituted $5.8 \%$. Kraft and Dürr (1997) described also two $\beta$ zones with the ranges of $2-3 \mathrm{~g} / 1$ for $\beta_{1}$-globulins and 3-6 g/l for $\beta_{2}$-globulins. On the other hand, Albergina et al. (2011) and Dede et al. (2014) presented only one $\beta$-fraction with mean relative concentrations of 11.05 and $11.21 \%$, respectively, in healthy cattle. These results of the overall $\beta$-fraction are comparable with the sum of $\beta_{1}$ - and $\beta_{2}$-globulins in our study. Transferrin and complement are the main proteins from the $\beta$-globulin fraction, which may correspond to the 2 subfractions $\left(\beta_{1}\right.$ and $\beta_{2}$ ) identified in our study (Cerón et al. 2010). Serum protein electrophoresis identified in sheep one overall $\beta$-globulin fraction. Similar findings were observed by Esmaeilnejad et al. (2014) in healthy sheep (on average $3.6 \mathrm{~g} / \mathrm{l}$ ), which can be compared with our results. Regarding the separation and identification of $\beta$-globulins in goats, the data available are contradictory. Piccione et al. (2010) reported, similarly to our results, one overall $\beta$-globulin fraction. In contrast, Alberghina et al. (2010) and Janku et al. (2011) separated the $\beta$-globulins into 2 zones, presumably caused by different support media used for electrophoretic separation. Poor correlation for $\beta$-globulins was found between protein electrophoresis performed by cellulose acetate and agarose gel that could be explained due to different migration of $\beta$-lipoproteins from this fraction (Martinez-Subiela et al. 2002). Moreover, immunoglobulins of the IgM class may migrate in the $\beta$ region, while IgA and IgE immunoglobulins in the $\beta-\gamma$ interzone, which may correspond to the subfraction $\beta_{2}$ identified in some animal species (Meyer and Harvey 2004). In the concentrations of $\gamma$-globulins, no significant differences were found between the evaluated ruminant species. Differences were observed only in the number of subfractions in this region. While in cows and goats the $\gamma$-globulins migrates as one overall fraction, in sheep they were separated in two subfractions $\left(\gamma_{1}\right.$ and $\left.\gamma_{2}\right)$. Esmaeilnejad et al. (2014) presented in sheep also two $\gamma$ zones, whereas similarly to our results the $\gamma_{1}$-globulin fraction was higher compared to $\gamma_{2}$-globulins. According to Kaneko (1997), immunoglobulins from the $\gamma$ fraction may migrate as fast or slow, which is in accordance with these two subfractions. In cows and goats, the $\gamma$-globulins were identified as one overall fraction, which is in accordance with the data presented by Piccione et al. (2010) and Alberghina et al. (2010, 2011). The aforementioned differences observed in the concentrations of the most of protein fraction resulted also in differences in $\mathrm{A} / \mathrm{G}$ ratios between the ruminant species, being the highest in sheep and the lowest in cows. According to Alberghina et al. (2011), the A/G ratio provides important diagnostic information, because it allows for electrophoretic pattern classification and identification of dysproteinaemias. 
In conclusion, the results of the current study showed significant differences in the electrophoretic pattern of serum proteins between cows, sheep, and goats. Differences were observed in the number and size of most of the protein fractions. These data demonstrate that the physiological protein concentrations are influenced by the evaluated species also among ruminants. Thus, for the most of serum protein fractions, species specific values should be available for precise interpretation of electrophoretic patterns. Seeing that serum protein electrophoresis may be a useful diagnostic tool also in ruminants, the obtained data would be useful for clinicians in the determination and differentiation of dysproteinaemias and in the evaluation of various pathological conditions such as inflammatory, infectious or neoplastic diseases, providing a basis for further specific laboratory investigations. Present results contribute to the widening of the knowledge about the physiological serum protein pattern in ruminants. However, because of some contradictory data found in the literature, further investigations are needed to yield satisfactory results.

\section{Acknowledgements}

This work was supported by the Slovak Research and Development Agency under contract No. APVV-0475-10 and by VEGA Scientific Grants No. 1/0447/14 and 1/0154/15 from the Ministry of Education.

\section{References}

Ahmadi-Hamedani M, Ghazvinian K, Kokhaei P, Barati M, Mahdavi A 2014: Comparison of effects of age and sex on serum protein electrophoretic pattern in one-humped camels (Camelus dromedarius) in Semnan, Iran. Open Vet J 4: 4-8

Alberghina D, Casella S, Vazzana I, Ferrantelli V, Giannetto C, Piccione G 2010: Analysis of serum proteins in clinically healthy goats (Capra hircus) using agarose gel electrophoresis. Vet Clin Path 39: 317-321

Alberghina D, Giannetto C, Vazzana I, Ferrantelli V, Piccione G 2011: Reference intervals for total protein concentration, serum protein fractions, and albumin/globulin ratios in clinically healthy dairy cows. J Vet Diagn Invest 23: 111-114

Azim W, Azim S, Ahmed K, Shafi H, Rafi T, Luqman M 2004: Diagnostic significance of serum protein electrophoresis. Biomedica 20: 40-44

Bossuyt X 2006: Advances in serum protein electrophoresis. Adv Clin Chem 42: 43-80

Bossuyt X, Claeys R, Bogaert G, Said HI, Wouters C, Groven C, Sneyers L, Marien G, Gorus F 2001: Reference values for the five electrophoretic serum protein fractions in Caucasian children by capillary zone electrophoresis. Clin Chem Lab Med 39: 970-972

Cerón JJ, Caldin M, Martinez-Subiela S 2010: Electrophoresis and acute phase protein measurement. In: Weiss DJ, Wardrop KJ (Eds.): Schalm's Veterinary Hematology. $6^{\text {th }}$ ed., Blackwell Publishing Ltd., Ames, Iowa, pp.1157-1161

Cyrillo FC, Leal ML do R, Benesi FJ, Della Libera AMM de P 2006: Dynamics of serum proteins during the estrous cycle of goats bred in Brazil and naturally infected by caprine arthritis encephalitis virus. Revista Arquivos do Instituto Biológico 73: 41-44

Dede S, Altug N, Deger Y, Ozdal N, Ceylan E 2014: Serum biochemical profile and protein fractions in cattle with Theileriosis. Revue Méd Vét 165: 137-143

Eckersall PD, Bell R 2010: Acute phase proteins: Biomarkers of infection and inflammation in veterinary medicine. Vet J 185: 23-27

Esmaeilnejad B, Tavassoli M, Asri-Rezaei S, Dalir-Naghadeh B, Pourseyed SH 2014: Evaluation of serum total protein concentration and protein fractions in sheep naturally infected with Babesia ovis. Comp Clin Path 23: 151-155

Fayos M, Couto CG, Iaybik MC, Wellman ML 2005: Serum protein electrophoresis in retired racing Greyhounds. Vet Clin Path 34: 397-400

Fernandez SY, Jesus EEV, Paule BJA, Uzeda RS, Almeida MAO, Guimaraes JE 2006: Proteinogram of alpine goat naturally infected by gastrointestinal parasites. Arq Bras Med Vet Zootec 58: 279-282

França RT, Costa MM, Martins DB, Pagnoncelli M, Leal ML, Mazzanti CM, Palma HE, Kunert CP, Paim FC, dos Anjos Lopes ST 2011: Protein profile of buffaloes of different ages. Acta Sci Vet 39: 995-999

Janku L, Pavlata L, Misurova L, Filípek J, Pechova A, Dvorak R 2011: Levels of protein fractions in blood serum of periparturient goats. Acta Vet Brno 80: 185-190

Joliff CR 1991: Agarose gel electrophoresis in the acute and chronic inflammatory states. Clin Immunol Newsl 11: $132-135$

Joliff CR 1992: Analysis of the plasma proteins. J Clin Immunoassay 15: 151-161 
Kaneko JJ 1997: Serum proteins and the dysproteinemias. In: Kaneko JJ (Ed.): Clinical Biochemistry of Domestic Animals. $5^{\text {th }}$ edn, Academic Presss, London, United Kingdom, pp. 117-138

Keay G, Doxey DL 1981: Species characteristics of serum proteins demonstrated after agarose gel electrophoresis. Vet Res Commun 5: 263-270

Keren DF 2003: Protein electrophoresis in clinical diagnosis. Edward Arnold Ltd., London, 415 p.

Kraft W, Dürr U 1997: Clinical laboratory diagnostic in veterinary medicine (in German). Schattauer, Stuttgart, $368 \mathrm{p}$.

Luraschi P, Dea E, Franzini C 2003: Capillary zone electrophoresis of serum proteins: effects of changes analytical conditions. Clin Chem Lab Med 41: 782-786

Lutz H, Riond B, Wenger-Riggenbach B, Hofmann-Lehmann R 2009: Serum protein concentrations from clinically healthy horses determined by agarose gel electrophoresis. Vet Clin Path 38: 73-77

Martinez-Subiela S, Tecles F, Montes A, Gutiérrez C, Cerón JJ 2002: Effects of haemolysis, lipaemia, bilirubinaemia and fibrinogen on protein electrophoretogram of canine samples analysed by capillary zone electrophoresis. Vet J 164: 261-268

Meyer D, Harvey JW 2004: Veterinary laboratory medicine: Interpretation and diagnosis. $3^{\text {rd }}$ edn, Saunders, $368 \mathrm{p}$.

O’Connell TX, Horite TJ, Kasravi B 2005: Understanding and interpreting serum protein electrophoresis. Am Fam Physician 71: 105-112

Piccione G, Casella S, Lutri L, Vazzana I, Ferrantelli V, Caola G 2010: Reference values for some haematological, haematochemical, and electrophoetic parameters in the Girgentana goat. Turk J Vet Anim Sci 34: 197-204

Piccione G, Messina V, Alberghina D, Giannetto C, Caselle S, Assenza A 2012: Seasonal variations in serum protein fractions of dairy cows during different phisiological phases. Comp Clin Path 21: 1439-1443

Pérez JM, González FJ, Granados JE, Pérez MC, Fandos P, Soriguer RC, Serrano E 2003: Hematologic and biochemical reference intervals for Spanish ibex. J Wildl Dis 39: 209-215

Riond B, Wenger-Riggenbach B, Hofmann-Lehmann R, Lutz H 2009: Serum protein concentrations from clinically healthy horses determined by agarose gel electrophoresis. Vet Clin Path 38: 73-77

Wijnen PA, Van Dieijen-Visser MP 1996: Capillary electrophoresis of serum proteins. Reproducibility, comparison with agarose gel electrophoresis and a review of the literature. Eur J Clin Chem Clin Biochem 34: 535-545 